\title{
Level of Knowledge and Attitude of Kualanamu International Airport Employee About Basic Life Support
}

\author{
Angeline $^{1}$, Ahmad Yafiz Hasby ${ }^{2}$, Meriza Martineta ${ }^{3}$, Ferryan Sofyan ${ }^{4}$ \\ ${ }^{1}$ Faculty of Medicine, Universitas Sumatera Utara, North Sumatera, Indonesia \\ ${ }^{2}$ Department of Anestesiology and Intensive Therapy, Universitas Sumatera Utara, North Sumatera, Indonesia \\ ${ }^{3}$ Department of Nutrition, Universitas Sumatera Utara, North Sumatera, Indonesia \\ ${ }^{4}$ Department of Ear,Nose, and Throat, Universitas Sumatera Utara, North Sumatera, Indonesia
}

\begin{abstract}
Background. All communities should teach about basic life support (BLS) perfectly for workers who related to giving first aid, either is the airport. BSL is an effort made to maintain the life of someone who danger that can get worse or death if it's not treated immediately. BLS in the first hour can reduce up to $85 \%$ of mortality. The study aims to evaluate the level of knowledge and attitude of BSL of employees.

Method. This study used descriptive of Kualanamu International Airport (KIA) terminal employees with a cross-sectional design. Inclusion criteria were willing to accompany the research by signing the respondent's consent form and answer the entire questionnaire of BLS.

Result. Samples in this study were 224 respondents or employers. The percentage of male dan female was $87.9 \%$ and $12.1 \%$, age of group 18-40 years, they had a high school education level $64.7 \%$, adequate knowledge $73.2 \%$ and good attitude $51,3 \%$.

Conclusion: This study showed that KIA employees had adequate knowledge and a good attitude towards BLS

Keyword: Basic Life Support, Knowledge, Attitude.

ABSTRAK

Latar belakang. Semua masyarakat harus diajarkan tentang bantuan hidup dasar (BHD) dengan sempurna terutama bagi pekerja yang terkait dengan pemberian pertolongan pertama, termasuk di bandara. BHD adalah upaya yang dilakukan untuk menjaga kehidupan seseorang dari bahaya yang bisa semakin parah atau mati jika tidak segera ditangani. BHD pada jam pertama dapat
\end{abstract}

\footnotetext{
*Corresponding author at: Faculty of Medicine, Universitas Sumatera Utara, Medan, North Sumatera, Indonesia

E-mail address: gui.angeline@yahoo.com
} 
mengurangi hingga $85 \%$ kematian. Penelitian ini bertujuan untuk mengevaluasi tingkat pengetahuan dan sikap BHD karyawan.

Metode. Penelitian ini menggunakan metode deskriptif terhadap karyawan terminal Bandara Internasional Kualanamu dengan desain potong-lintang. Kriteria inklusi adalah yang bersedia mengikuti penelitian dengan menandatangani formulir persetujuan responden dan menjawab seluruh kuesioner BHD.

Hasil. Sampel dalam penelitian ini adalah 224 responden. Persentase laki-laki dan perempuan adalah 87,9\% dan 12,1\%, usia kelompok antara 18-40 tahun, mereka memiliki tingkat pendidikan SMA $64,7 \%$, pengetahuan yang memadai 73,2\% dan sikap baik 51,3\%.

Kesimpulan: Studi ini menunjukkan bahwa karyawan KIA memiliki pengetahuan yang memadai dan sikap yang baik terhadap BHD

Kata kunci: Dukungan Kehidupan Dasar, Pengetahuan, Sikap.

Received 28 June 2021 | Revised 05 August 2021 | Accepted 30 August 2021

\section{Introduction}

The part of emergency services is to improve health development. The improvement of service quality in rescue victim or emergency patients realizes an emergency patients system need that carry out in an integrated involving several sides.[1] The situation of accident victims can get worse or lead to death if not treated quickly. These guidelines are intended to support members of our communities who may be called upon to act in an emergency and to help saves someone's life. This includes members of the public, children and family members, first responders, and those with a duty to respond (e.g. lifeguards, first aiders).[2] BSL is an effort to sustain the life of someone who is in danger of life. Frame said that BSL skills can be taught to anyone.[3] All levels of communities should be taught about basic life most important for workers related to giving first aid.[4] Ideally, everyone knows the basic first aid techniques and takes regular training to ensure that the knowledge goes on.[5] Often, a bystander may be reluctant to offer help, especially CPR, because they are afraid that if they do something wrong, they will sue for injury (although unintentional) or death. Delays that result in emergency care can be a determining factor in the survival of victims, and in most countries, these delays are perfectly unwarranted. "Good Samaritan Law" will be imposed on someone who giving help (such as first aid, CPR, or AED treatment) in an emergency to injured people in a voluntary capacity, without expecting monetary compensation, and not from professional rescuers or medical professionals. Most countries have a legal version in place, with some variations in details [6].

The study aims to evaluate the level of knowledge and attitude of basic life support of employees in Kualanamu International Airport. 


\section{Method}

This study used a descriptive study with a cross-sectional design in the Kualanamu International Airport terminal are using the total sampling technique. Inclusion criteria were employees operating at the Kualanamu International Airport (KIA) terminal who were willing to accompany the research by signing the respondent's consent form and answer the entire questionnaire of BLS. Exclusion criteria were employees operating at the KIA terminal who did not complete the questionnaires and answer questionnaires with more than one answer. Data obtained directly from the data source was the distribution of a questionnaire to research subjects and researchers immediately collect the questionnaire again when it was complete. The study does during working hours between changing shifts of an employee operating at the KIA terminal. The data that had been collected was processed using statistical software and analyzed afterward presented in tabular form.

\section{Results}

In table1, samples in this study were 224 respondents who met inclusion criteria. it could be seen that the percentage of airport employees of the male (87.9\%) was more than the percentage of airport employee of the female (12.1\%), age of group 18-40 years. They had a high school education level of $64.7 \%$ (145 people)

Table 1 Demographics of respondents

\begin{tabular}{lcc}
\hline \multicolumn{1}{c}{ Characteristics } & $\mathrm{n}=224$ & $(\%)$ \\
\hline Sex & 197 & 87.9 \\
$\quad$ Male & 27 & 12.1 \\
$\quad$ Female & & \\
Age (years) & 217 & 96.9 \\
$\quad$ 18-40 & 7 & 3.1 \\
$\quad 41-65$ & & \\
Education status & 145 & 64.7 \\
$\quad$ High school & 79 & 35.3 \\
$\quad$ Bachelor (S1/S2/S3) & & \\
Occupation & 102 & 45.5 \\
$\quad$ Airport Security & 53 & 23.7 \\
$\quad$ Airport Rescue and Fire Fighting & 36 & 16.1 \\
$\quad$ Airport Operation and Services & 33 & 14.7 \\
$\quad$ Others & & \\
$\quad$
\end{tabular}

In table 2, showed that 24 people had a lack of knowledge (10.7\%), then 164 people had adequate knowledge (73.2\%), and 36 people had good knowledge (16.1\%). 
Table 2 Level of Knowledge of BLS

\begin{tabular}{lcc}
\hline Level of Knowledge & $\mathrm{n}$ & $(\%)$ \\
\hline Lack of knowledge & 24 & 10.7 \\
Adequate knowledge & 164 & 73.2 \\
Good knowledge & 36 & 16.1 \\
Total & 224 & 100 \\
\hline
\end{tabular}

Table 3 showed that 13 people had less attitude $(5,8 \%)$, then 96 people had enough attitude $(42,9 \%)$, and 115 people had good attitude $(51,3 \%)$.

Table 3 Attitude of BLS

\begin{tabular}{lcc}
\hline \multicolumn{1}{c}{ Attitude } & $\mathrm{n}$ & $(\%)$ \\
\hline Less attitude & 13 & 5,8 \\
Enough attitude & 96 & 42,9 \\
Good attitude & 115 & 51,3 \\
Total & 224 & 100 \\
\hline
\end{tabular}

\section{Discussion}

BLS refers to the care healthcare providers and public safety professionals provide to patients who are experiencing respiratory arrest, cardiac arrest, or airway obstruction. BLS includes psychomotor skills for performing high-quality cardiopulmonary resuscitation (CPR), using an automated external defibrillator (AED), and relieving an obstructed airway for patients of all ages. BLS also focuses on the integration of the following key skills to help rescuers achieve optimal patient outcomes: Critical thinking: clear and rational thinking based on facts presented and the learner's experience and expertise. Problem-solving: identifying solutions to issues that arise using readily available. Resources. communication: a closed-loop process involving a sender, message, and receiver. Team dynamics: integration and coordination of all team members working together toward a common goal.[7] There is a correlation between the level of knowledge and the application of BSL Makassar BASARNAS employees in handling emergency cases.[8]

Based on the study results, it could conclude that the level of knowledge of airport employees had adequate basic life support. Budiman and Riyanto study, that several factors influence knowledge, namely education, information, social, culture, economy, environment, experience, and age.[9] Azwar study, that several factors influence the formation of one's attitudes, including personal experience, the influence of others, culture, mass media, and emotional elements.[10] Furthermore, the attitude towards airport employees had a good attitude towards basic life support.

\section{Conclusion}

This study showed that KIA employees had adequate knowledge and a good attitude towards BLS. 


\section{REFERENCES}

[1] Depkes RI. Kesehatan Kegawatdaruratan dan Penanganannya. Jakarta: Depkes RI. 2016

[2] Perkins G, Colquhoun M, Deakin CD, Smith C, Smyth M, Barraclough N, Yeates L, et al. Adult basic life support Guidelines. Published May 2021.

[3] Frame, Scott B. PHTLS: Basic and Advanced Prehospital Trauma Life Support ( $5^{\text {th }}$ ed). Missouri; Mosby 2003.

[4] Resuscitation Council. 2010, Adult Basic Life Support. accessed 29 Maret 2019, Available at: http://www.resus.org.uk/pages/bls.pdf.

[5] International first aid and resuscitation guidelines. For National Society First Aid Programme Managers, Scientific Advisory Groups, First Aid Instructors and First Responders. 2011

[6] CPR Seattle., The Good Samaritan Law-How does that work, exactly? 2015. accessed 10 April 2019, Available at: http://www.cprseattle.com/blog/the-good-samaritan-law how-does-thatwork-exactly.

[7] Basic Life Support for Healthcare Providers. Provider Handbook. The American National Red Cross. 2015

[8] Sri Ayu Lestari Wulandari, Ami Febriza. Hubungan Tingkat Pengetahuan Terhadap Pengaplikasian Basic Life Support (BLS) Pegawai Basarnas Makassar Dalam Menangani Kasus Kegawatdaruratan”. Undergraduate Thesis, 20 Feb 2020

[9] Budiman dan Riyanto A. Kapita Selekta Kuesioner Pengetahuan dan Sikap dalam Penelitian Kesehatan. Metode Penelitian, Salemba Medik.2013 http://ucs.sulsellib.net//index.php?p=show_detail\&id=91002

[10] Azwar, S. Sikap Manusia: Teori dan Pengukurannya. Yogyakarta: Liberty, 1988 